\title{
Flood control in small urban rivers: an example of river projects in Tokyo
}

\author{
K. Sato ${ }^{1}$, K. Masuhara ${ }^{1}$, S. Mochida ${ }^{1}$, T. Yamamoto ${ }^{2}$, \\ H. Gotoh ${ }^{3}$ \& M. Takezawa ${ }^{3}$ \\ ${ }^{I}$ Tokyo Metropolitan Government, Japan \\ ${ }^{2}$ Chuo College of Technology, Japan \\ ${ }^{3}$ Department of Civil Engineering, Nihon University, Japan
}

\begin{abstract}
The Tokyo Metropolitan Government (TMG) has conducted a variety of river projects to protect citizens and their property from damage due to flooding, storm surges, and landslides. Projects have also been undertaken to improve and create riversides that support nature, and to protect and restore the natural environment. The hardening of urban and inner city areas with high population densities and developed areas have relatively poor water retention and flood prevention properties. Consequently, these areas have sustained extensive water damage during times of heavy rainfall and flooding. Indeed, extensive flood damage was observed in downtown areas as recently as September 2005 and August 2008, demonstrating the need to implement additional flood mitigation measures to prevent flood damage in the metropolitan area. The number of rivers currently under the direct management of the TMG is 61 class A rivers and two class B rivers, which together measure $494.82 \mathrm{~km}$. In addition, the city office of the TMG also controls 33 class A rivers and 13 class $B$ rivers, which together equal $215.91 \mathrm{~km}$. The main projects undertaken by the TMG is small river development, reinforce of lowland, improvement of the river environment for ecology, improvement of sediment disaster control facilities, development of software programs, river enlightenment activities and improved shoreline protection measures. In 2010, the total costs of river projects amounted to approximately JPY 65 billion. Small river projects are primarily concerned with the construction of several regulation reservoirs and river diversion channels. Conversely, the development of high tide breakwater structures and the reinforcement of rivers in lowland areas using super levees
\end{abstract}


are important large-scale projects. Recently, special emphasis has been placed on earthquake measures, such as disaster prevention piers or water gates. In this paper, we describe flood control measures of small rivers in the Tokyo metropolitan area, with particular emphasis on regulating reservoirs.

Keywords: flood control, small rivers, regulating reservoir, disaster prevention.

\section{Introduction}

Recently, extensive flood damage due to heavy rainfall, tsunamis or the failure of levees has been reported around the world. In many cases, abnormal weather and extensive deforestation associated with urban development has been responsible for this extensive damage. In many cases, the severity of these floods has primarily been due to a lack of flood plain management. River improvement measures have numerous functions, most of which are related to ensuring the safety of civilian lives and property from flood damage, securing the water resources that support a rich lifestyle, protecting areas from erosion damage and landslides, ensuring safety and serenity along coastal areas, maintaining the information networks that protect lives, preventing disasters, and creating pleasant water environments. In order to achieve these aims, it is necessary to improve river channels by constructing floodways, detention basins, flood control basins, water reservoirs, underground discharge channels, storm water systems, etc.

River information systems are also important for protecting lives. The TMG has conducted a variety of river projects to protect citizens and their property from water damage, such as that caused by floods or storm surges and landslides, and also to create riversides environments that are rich in nature, and to protect the natural environment.

The Tokyo Metropolitan Area, which has primarily expanded along an eastwest axis, is bounded in the west by the Okuchichibu Mountains with a central plateau referred to as the Musashino Plateau and eastern lowlands bordering Tokyo Bay. Tokyo's rivers generally flow westward into Tokyo Bay.

Figures 1 and 2 show the main islands of the Japanese archipelago and the Tokyo metropolis, respectively. Tokyo is drained by five major river systems/consists of five major river catchments; the Tama River system that flows eastward and empties into Tokyo Bay, the Tsurumi River system that runs through the southern region of the Tama Hills, the Arakawa River system runs through the Musashino Plateau, the Tone River system runs from north to south in the eastern lowlands, and the other river systems run directly into the sea.

A total of 107 rivers with a total length of approximately $858 \mathrm{~km}$ drain the Tokyo metropolis region. Of these, the TMG manages about $711 \mathrm{~km}$ of 105 rivers; 46 of these rivers are managed by Tokyo Special Ward Governments and about $33 \mathrm{~km}$ of 20 small rivers (locally designated rivers) are managed by municipalities $[1,2]$. 


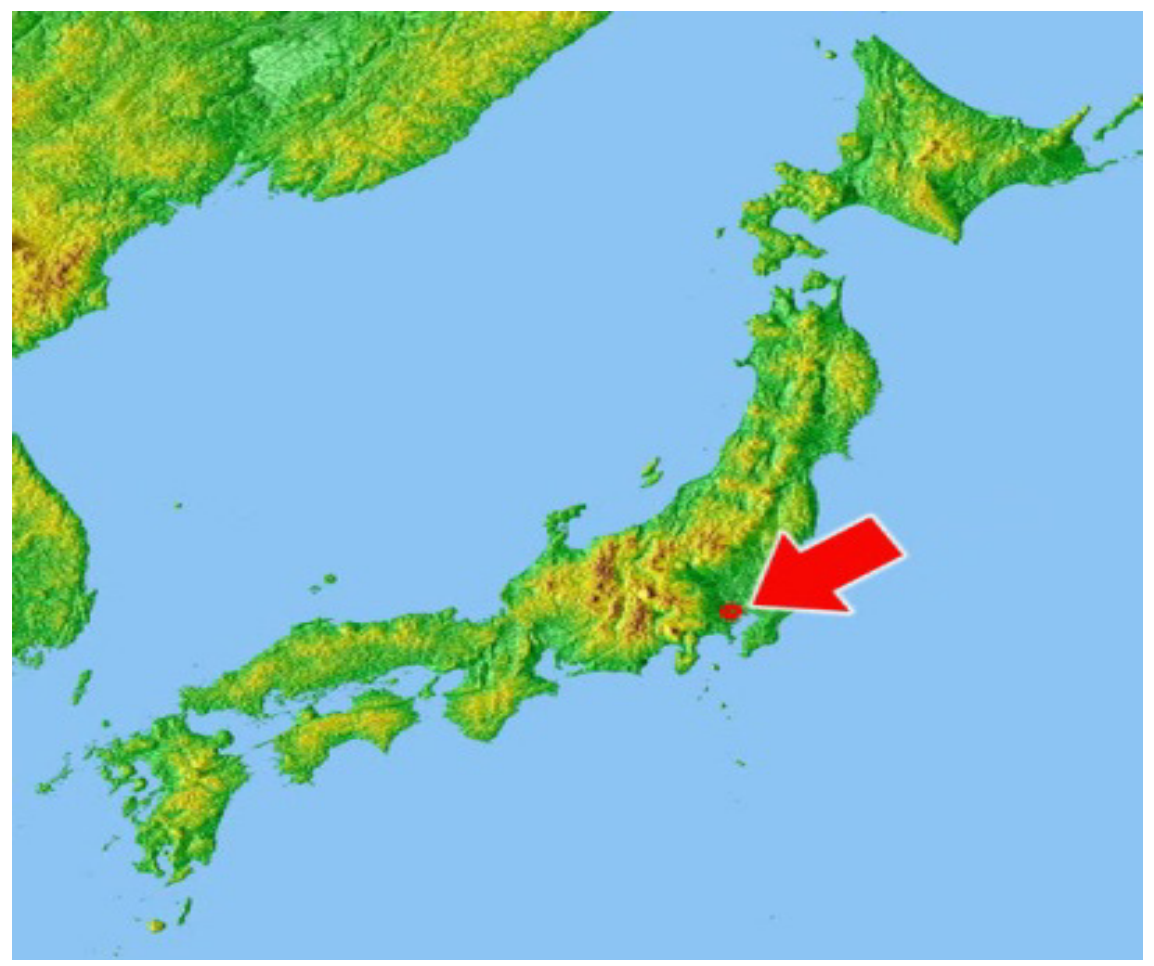

Figure 1: $\quad$ The main islands of the Japanese archipelago.

\section{- Rivers and River Systems in Tokyo}

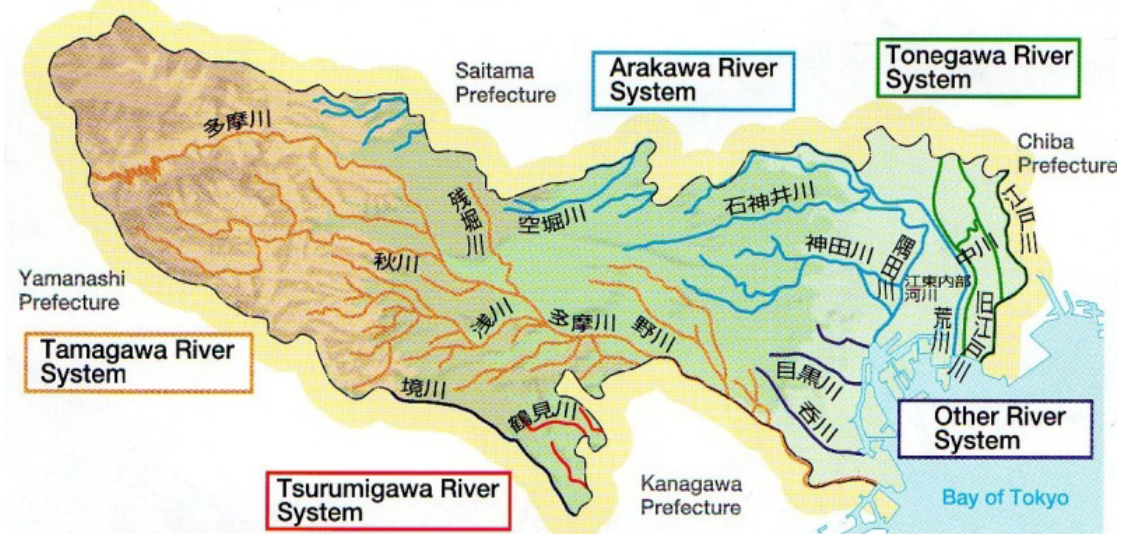

Figure 2: The Tokyo metropolitan area. 


\section{Flood hazards in Tokyo}

Dates on which extensive damage to properties in the Tokyo metropolitan area occurred are shown in Table $1[3,4]$.

Table 1: $\quad$ Characteristics of floods and associated damage in Tokyo.

\begin{tabular}{|c|c|c|c|c|}
\hline Year & $\begin{array}{c}\text { Frequency } \\
\text { (events/year) }\end{array}$ & $\begin{array}{c}\text { Affected area } \\
\text { (ha) }\end{array}$ & $\begin{array}{c}\text { Above ground } \\
\text { (houses) }\end{array}$ & $\begin{array}{c}\text { Below ground } \\
\text { (houses) }\end{array}$ \\
\hline 1975 & 12 & 748.1 & 7,676 & 403 \\
\hline 1976 & 5 & 385.0 & 6,145 & 2,190 \\
\hline 1977 & 12 & 126.7 & 2,677 & 214 \\
\hline 1978 & 2 & 284.2 & 5,353 & 2,338 \\
\hline 1979 & 9 & 322.9 & 4,426 & 1,352 \\
\hline 1980 & 2 & 12.3 & 266 & 5 \\
\hline 1981 & 4 & $2,429.4$ & 45,780 & 9,982 \\
\hline 1982 & 7 & $2,539.0$ & 25,121 & 9,038 \\
\hline 1983 & 5 & 786.6 & 8,732 & 447 \\
\hline 1984 & 2 & 18.1 & 164 & 8 \\
\hline 1985 & 6 & 322.1 & 9,344 & 1,645 \\
\hline 1986 & 7 & 46.1 & 5,851 & 838 \\
\hline 1987 & 7 & 183.7 & 6,765 & 1,056 \\
\hline 1988 & 5 & 7.88 & 421 & 46 \\
\hline 1989 & 6 & 93.46 & 3,312 & 2,187 \\
\hline 1990 & 7 & 37.40 & 963 & 110 \\
\hline 1991 & 10 & 190.60 & 3,315 & 613 \\
\hline 1992 & 4 & 21.97 & 427 & 106 \\
\hline 1993 & 6 & 390.32 & 5,802 & 2,867 \\
\hline 1994 & 7 & 15.35 & 556 & 85 \\
\hline 1995 & 4 & 4.23 & 152 & 68 \\
\hline 1996 & 2 & 5.52 & 64 & 16 \\
\hline 1997 & 9 & 27.99 & 193 & 135 \\
\hline 1998 & 6 & 9.27 & 320 & 236 \\
\hline 1999 & 9 & 180.06 & 2,932 & 3,648 \\
\hline 2000 & 9 & 20.63 & 748 & 264 \\
\hline 2001 & 7 & 16.74 & 314 & 198 \\
\hline 2002 & 9 & 14.42 & 453 & 518 \\
\hline 2003 & 8 & 11.16 & 322 & 164 \\
\hline 2004 & 5 & 43.62 & 1,041 & 955 \\
\hline 2005 & 8 & 180.43 & 2,660 & 3,576 \\
\hline 2006 & 5 & 1.97 & 82 & 44 \\
\hline 2007 & 6 & 10.75 & 127 & 57 \\
\hline 2008 & 7 & 20.56 & 323 & 307 \\
\hline 2009 & 5 & 10.77 & 225 & 163 \\
\hline
\end{tabular}


Table 2 shows the highest values recorded for maximum hourly rainfall and Table 3 shows the maximum daily rainfall for the Tokyo metropolitan area. These records values were recorded by the Tokyo District Meteorological Observatory before 2009 [3, 4].

Table 2: $\quad$ Largest maximum hourly rainfall values in Tokyo.

\begin{tabular}{|c|c|c|c|}
\hline Ranking & Date & $\begin{array}{c}\text { Amount of } \\
\text { rainfall } \\
(\mathrm{mm} / \mathrm{hr})\end{array}$ & $\begin{array}{c}\text { Weather } \\
\text { conditions }\end{array}$ \\
\hline 1 & August 29, 1999 & 115.0 & - \\
\hline 2 & September 4, 2005 & 112.0 & - \\
\hline 3 & July 31, 1939 & 88.7 & - \\
\hline 4 & July 4, 2000 & 82.5 & $\begin{array}{c}\text { Torrential } \\
\text { Downpour }\end{array}$ \\
\hline 5 & July 22, 1981 & 80.0 & - \\
\hline
\end{tabular}

Table 3: $\quad$ Largest maximum daily rainfall values in Tokyo.

\begin{tabular}{|c|c|c|c|}
\hline Ranking & Date & $\begin{array}{c}\text { Amount of rainfall } \\
(\mathrm{mm} / \mathrm{hr})\end{array}$ & $\begin{array}{c}\text { Weather } \\
\text { conditions }\end{array}$ \\
\hline 1 & September 22-27, 1958 & 444.1 & Typhoon \\
\hline 2 & August 26-28, 1993 & 345.0 & Typhoon \\
\hline 3 & September 11-12 & 313.0 & Typhoon \\
\hline 4. & August 7-11, 1910 & 283.9 & Storm \\
\hline 5 & June 29, 1938 & 278.3 & \\
\hline
\end{tabular}

The most severe typhoons to hit the Tokyo metropolitan area were as follows. Typhoon Kathleen hit the Kanto area on September 15, 1947 resulting in the collapse of the Tone River levee in the upper reaches on September 16, 1947. As a result, the muddy stream entered the Tokyo metropolitan area after several days, causing extensive sedimentation of the urban areas downstream/old flood plain. The maximum hourly rainfall was $34.7 \mathrm{~mm} /$ hour, the total amount of rainfall $166.8 \mathrm{~mm}$ (September 13-15), the area inundated was $114.32 \mathrm{~km}^{2}$, with above- and below-ground damage caused to 80,041 and 45,167 houses, respectively, and 11 fatalities [5].

Typhoon Kitty occurred, the abnormal Takashio (Storm Surge) due to the typhoon occurring at high tide in Tokyo Bay. As a result, extensive flooding occurred in the low-lying downtown regions of the Tokyo metropolitan area on September 1, 1949. The maximum hourly rainfall was $12.6 \mathrm{~mm} / \mathrm{hr}$, the total rainfall was $64.9 \mathrm{~mm}$ (August 31 - September 1), $92.01 \mathrm{~km}^{2}$ was inundated, with above- and belowground damage caused to 73,751 and 64,127 houses, respectively, and 122 fatalities [5].

Typhoon Kanogawa (Ida) caused a torrential downpour on September 26, 1958 since the meteorological observation in Japan started. Serious damage occurred along small rivers in the Tokyo Metropolitan area. The maximum 
hourly rainfall was $76.0 \mathrm{~mm} / \mathrm{hr}$, total rainfall was $392.5 \mathrm{~mm}$ (September 22-27), the area inundated was $211.03 \mathrm{~km}^{2}$, with above- and belowground damage caused to 123,000 and 340,404 houses, respectively, and 203 fatalities [5].

\section{Flood control}

Small river improvement projects have been undertaken to prevent damage due to flooding in the smaller rivers on areas of the plateau in central Tokyo. The projects typically involve construction or improvement of revetments, retention basins, regulating reservoirs and diversion channels. This has been necessary because urban and inner-city areas with high population densities and developed properties have experienced have lower water retention and flood prevention capacities. Consequently, it is these areas that have sustained extensive water damage during times of heavy rainfall. For example, the extensive flooding associated with the relatively recent downpours of September 2005 and August 2008 illustrated the need for further river development measures to prevent inundation of the metropolitan area.

Of the small rivers managed by the TMG, river improvement projects have been undertaken by the TMG so that these rivers can handle a rainfall intensity of $50 \mathrm{~mm} / \mathrm{hr}$. In areas where early river improvement is difficult, retention reservoirs have been built to store at least some of the floodwaters. As of 2011, approximately $209.8 \mathrm{~km} \mathrm{(65 \% )}$ of the small rivers under TMG management have been improved in the Tokyo metropolitan area. In addition, 34 regulating reservoirs and 9 diversion channels are planned in the future. 23 regulating reservoirs and 7 diversion channels were finished in 2010, and 4 regulating reservoirs and 1 diversion channel were constructed in 2011. Moreover, 8 regulating reservoirs and 1 diversion channel will be constructed shortly. Tables 4(a) $\sim 4$ (c) shows the regulating reservoirs and Table 5 shows the diversion channels in Tokyo [6].

The Kanda River/ Loop Road No.7 Underground Regulating Reservoir is a $4.5 \mathrm{~km}$ long underground tunnel with an inner diameter measuring $12.5 \mathrm{~m}$, built beneath Loop Road No.7. The tunnel can store approximately $540,000 \mathrm{~m}^{3}$ of flood water from the Kanda River and the Zenpukuji River to improve safety control of floods that often occur in the middle of the Kanda River.

The regulating reservoir, which was completed in March 2008, is capable of effectively storing water from each river under a variety of rainfall conditions, and has been very effective in reducing water damage in the Kanda River basin. The Kanda River basin had a mean hourly rainfall of about $50 \mathrm{~mm}$ and a total rainfall of about $150 \mathrm{~mm}$, which rapidly raised the water level in the river. However, the regulating reservoir constructed under Loop Road No.7 is capable of storing flood waters to its $94 \%$ of the total capacity, or about $505,000 \mathrm{~m}^{3}$, the largest volume ever received by this tunnel type reservoir, to successfully prevent flood damage. Figure 3 is the Kanda River Loop Road No.7 Underground Regulating Reservoir. The length and the drainage area of the Kanda River are $24.6 \mathrm{~km}$ and $105 \mathrm{~km}^{2}$, and the length and the drainage area of the Zenpukuji River are $10.5 \mathrm{~km}$ and $18.3 \mathrm{~km}^{2}$. The Ebara regulating reservoir 
Table 4(a): Completed regulating reservoirs in Tokyo.

\begin{tabular}{|c|c|c|c|c|}
\hline River name & Site name & $\begin{array}{l}\text { Site area } \\
\left(\mathrm{m}^{2}\right)\end{array}$ & $\begin{array}{c}\text { Storage } \\
\text { capacity } \\
\left(\mathrm{m}^{3}\right)\end{array}$ & $\begin{array}{c}\text { Year } \\
\text { completed }\end{array}$ \\
\hline Shakujii & Fujimiike & 21,000 & 33,800 & 2007 \\
\hline Shakujii & Shibakubo & 10,000 & 11,000 & 1980 \\
\hline Shakujii & Minamimachi & 8,000 & 12,000 & 1980 \\
\hline Shakujii & Mukoudai & 30,000 & 81,000 & 1980 \\
\hline Zenpukuji & Wadabori No.2 & 5,100 & 2,500 & 1978 \\
\hline Zenpukuji & Wadabori No.3 & 3,900 & 3,000 & 1978 \\
\hline Zenpukuji & Wadabori No.6 & 15,400 & 48,000 & 2007 \\
\hline Nogawa & Nogawa No.1 & 14,800 & 21,000 & 1980 \\
\hline Nogawa & Nogawa No.2 & 16,900 & 28,000 & 1989 \\
\hline Nogawa & Ohsawa & 43,100 & 90,000 & 2001 \\
\hline Shirako & $\begin{array}{l}\text { Bikunibashi } \\
\text { Upstream }\end{array}$ & 22,000 & 34,400 & 1985 \\
\hline Shirako & $\begin{array}{l}\text { Bikunibashi } \\
\text { Downstream }\end{array}$ & 15,400 & 212,000 & 2002 \\
\hline Myoshouji & Myoshouji No.1 & 11,000 & 30,000 & 1986 \\
\hline Myoshouji & Kitaekoda & 15,600 & 17,000 & 1986 \\
\hline Myoshouji & Ochiai & 9,600 & 50,000 & 1995 \\
\hline Myoshouji & Myoshouji No.2 & 11,300 & 100,000 & 1995 \\
\hline Myoshouji & Kamitakada & 16,600 & 160,000 & 1997 \\
\hline Kanda & $\begin{array}{l}\text { LoopNo.7 } \\
\text { (Underground) }\end{array}$ & & 540,000 & 2007 \\
\hline Zanbori & $\begin{array}{l}\text { National Park } \\
\text { (Showa) }\end{array}$ & 22,800 & 60,000 & 1987 \\
\hline Meguro & Funairiba & 2,900 & 55,000 & 1990 \\
\hline Meguro & Ebara & 11,400 & 200,000 & 2001 \\
\hline Yanase & Kanayama & 31,500 & 46,000 & 2006 \\
\hline Kasumi & Kasumigawa & 13,300 & 88,000 & 2006 \\
\hline Total & & & $1,922,700$ & \\
\hline
\end{tabular}

Table 4(b): Regulating reservoir under construction in 2011.

\begin{tabular}{|c|c|c|c|c|}
\hline River name & Site name & $\begin{array}{c}\text { Site area } \\
\left(\mathrm{m}^{2}\right)\end{array}$ & $\begin{array}{c}\text { Storage } \\
\text { capacity }\left(\mathrm{m}^{3}\right)\end{array}$ & $\begin{array}{c}\text { Year } \\
\text { scheduled } \\
\text { for } \\
\text { completion }\end{array}$ \\
\hline Furukawa & Furukawa & & 135,000 & 2015 \\
\hline Kurome & Kuromebashi & 14,000 & 221,000 & Use of a part \\
\hline Shirako & Shirakogawa & & 212,000 & 2017 \\
\hline Myoshouji & Saginomiya & 10,000 & 35,000 & 2012 \\
\hline Total & & & 603,000 & \\
\hline
\end{tabular}


Table 4(c): $\quad$ Planned regulating reservoirs.

\begin{tabular}{|c|c|c|c|}
\hline River name & Site name & $\begin{array}{c}\text { Site area } \\
\left(\mathrm{m}^{2}\right)\end{array}$ & Storage capacity $\left(\mathrm{m}^{3}\right)$ \\
\hline Shirako & Oizumiinokashira & & 28,600 \\
\hline Shirako & Bikuni Midstream & & 11,700 \\
\hline Zenpukuji & Wadabori Park & & 17,500 \\
\hline Zenpukuji & Zenpukuji & & 35,000 \\
\hline Myoshouji & Nishiochiai & 11,200 & 100,000 \\
\hline Ochiai & Fudobashi & 11,000 & 7,300 \\
\hline Ochiai & Shitayabashi & 12,000 & 9,500 \\
\hline Zanbori & Zanborigawa & 50,000 & 60,000 \\
\hline Total & & & 269,000 \\
\hline
\end{tabular}

Table 5: $\quad$ Existing and proposed diversion channels in Tokyo.

\begin{tabular}{|c|c|c|c|c|c|}
\hline $\begin{array}{l}\text { River } \\
\text { name }\end{array}$ & Site name & $\begin{array}{l}\text { Length } \\
\text { (m) }\end{array}$ & Section (m) & $\begin{array}{c}\text { Discharge } \\
\left(\mathrm{m}^{3} / \mathrm{s}\right)\end{array}$ & $\begin{array}{c}\text { Year } \\
\text { completed }\end{array}$ \\
\hline Kanda & Edogawabashi & 1,640 & $\begin{array}{c}2 \square-7.2 \times 7.5 \\
\text { Double }\end{array}$ & 230 & 1977 \\
\hline Kanda & Takadanobaba & 1,460 & $\begin{array}{c}2 \square-6.6 \times 6.65 \\
\text { Double }\end{array}$ & 330 & 1982 \\
\hline Kanda & $\begin{array}{l}\text { Suidoubashi } \\
\text { (1) }\end{array}$ & 680 & $\begin{array}{c}1 \square-7.2 \times 7.5 \\
\text { Single }\end{array}$ & 125 & 1971 \\
\hline Kanda & $\begin{array}{c}\text { S Suidoubashi } \\
\text { (2) }\end{array}$ & 960 & $\begin{array}{c}1 \square-7.7 \times 7.45 \\
1 \square-9.5 \times 7.45 \\
\text { Double }\end{array}$ & 270 & 1986 \\
\hline Kanda & Ochanomizu & 1,300 & $\begin{array}{c}1 \phi-8.8 \\
\text { Single } \\
1 \square- \\
6.8 \times 8.0 \sim 6.45\end{array}$ & 80 & 2000 \\
\hline Shakujii & Asukayama & 250 & $\begin{array}{l}2 \phi-6.5 \\
\text { Double }\end{array}$ & 480 & 1982 \\
\hline Sen & Koganei & 1,900 & $\begin{array}{l}1 \phi-2.8 \\
\text { Single }\end{array}$ & 20 & 1978 \\
\hline Misawa & Misawakawa & 2,670 & $\begin{array}{c}1 \phi-5.3 \sim 8.1 \\
\text { Horse shoe- } \\
\text { shaped }\end{array}$ & 107 & 1983 \\
\hline Iruma & Irumagawa & 1,230 & $\begin{array}{c}1 \phi-2.2 \text { Single } \\
1 \square-2.0 \times 2.0\end{array}$ & 10 & 2013 \\
\hline Yazawa & Yazawagawa & - & - & - & - \\
\hline
\end{tabular}


was constructed near a busy shopping area in downtown Tokyo along the Meguro River in 1991-2001 because this area is low lying and frequently damaged by heavy rainfall and occasionally by typhoons. The Ebara regulating reservoir was designed to handle a maximum flow rate of $6 \mathrm{~m}^{3} / \mathrm{s}$ and has a water storage capacity of $200,000 \mathrm{~m}^{3}$. The reservoir is $30.5 \mathrm{~m}$ deep and has an area of $8,970 \mathrm{~m}^{2}$ and is designed for the rainfall intensity $50 \mathrm{~mm} / \mathrm{hr}$. The length and the drainage area of the Meguro River are $7.82 \mathrm{~km}$ and $45.8 \mathrm{~km}^{2}$. Figures 3 shows the Kanda River Loop Road No.7 underground regulating reservoir and Figure 4 shows the Meguro River Ebara regulating reservoir [7-9].

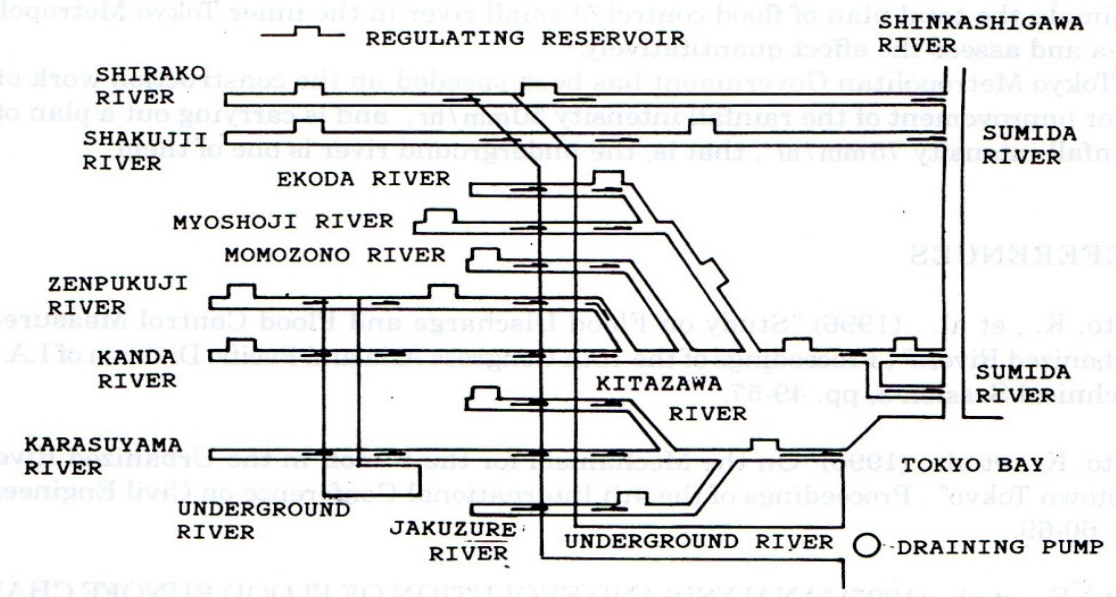

Figure 3: $\quad$ Kanda River loop road No.7 (underground river).

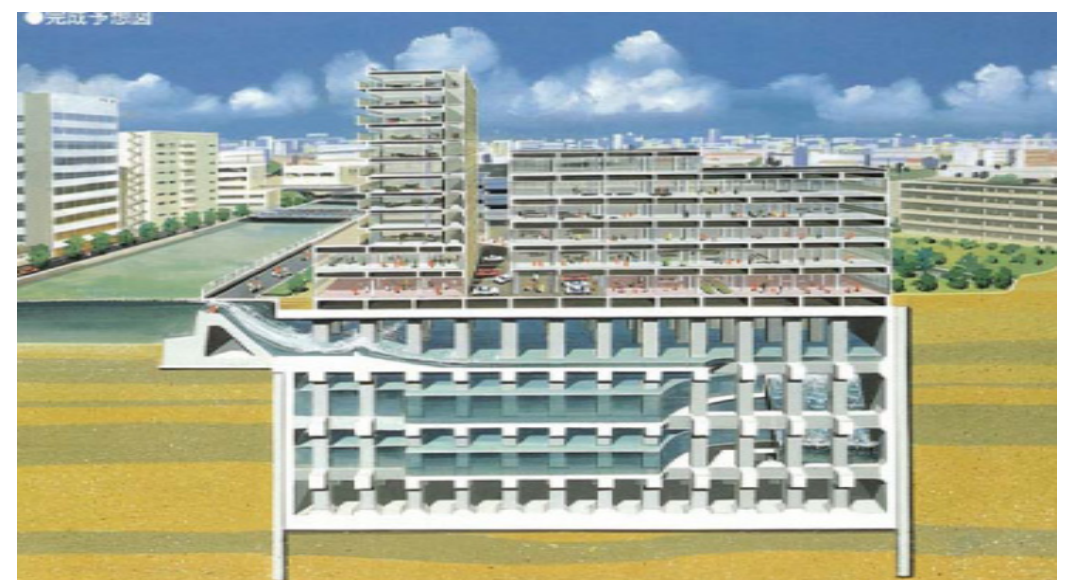

Figure 4: $\quad$ Meguro River: Ebara regulating reservoir. 
The basic response/mitigation measures for use against heavy rain in Tokyo were decided in 2007. Since then, the TMG has advanced the need for/has been involved in river improvements, improved sewers, basin measures, and integration of town planning within a regional setting. The five most important small rivers used for predicting flood hazards in Tokyo were identified by the Tokyo Metropolitan Council of Integrated Flood Control. One of these rivers is the Shirako River. Figure 5 shows an image of the regulating reservoirs constructed upstream and downstream of Bikunibashi along the Shirako River. Figure 7 show a tennis court on regulation reservoir of Bikunibashi. The Shirako River in the north of the Tokyo Metropolitan area has a length of $10 \mathrm{~km}$ and a drainage area of $25 \mathrm{~km}^{2}$. A group of regulating reservoirs (storage capacity $34,400 \mathrm{~m}^{3}$ ) is used as part of a tennis court and playground complex, as shown in Figure 6.

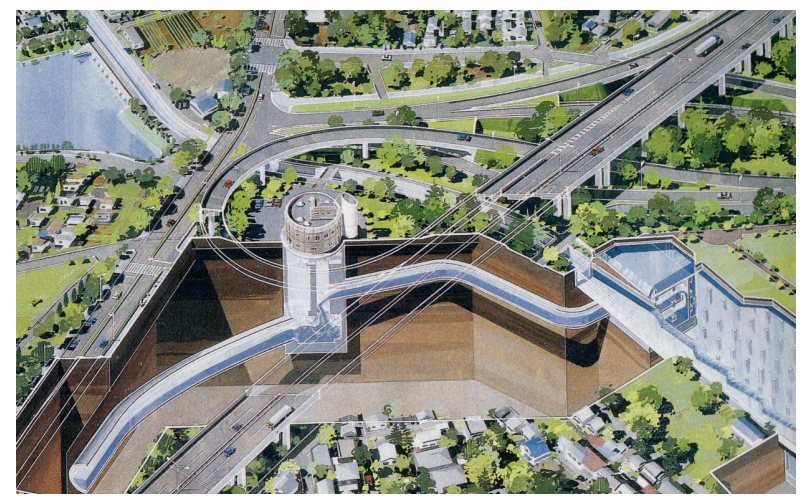

Figure 5: A group of regulating reservoirs along the Shirako River.

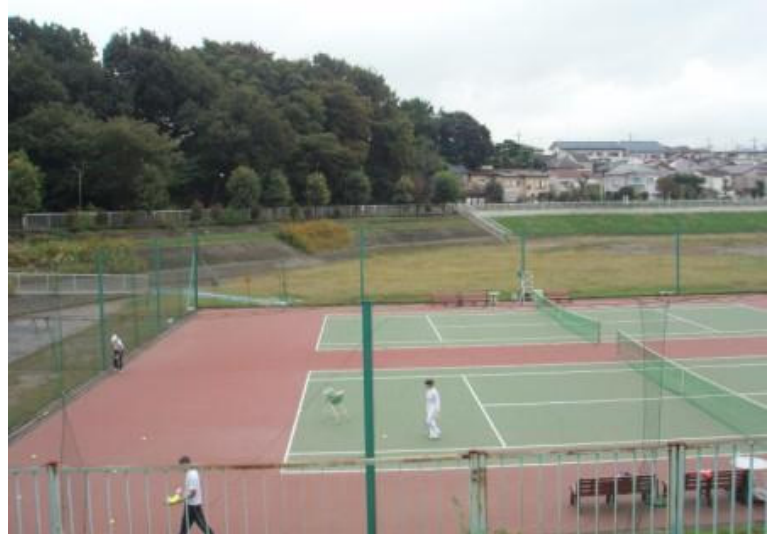

Figure 6: Tennis court on regulating reservoir. 
Part of the regulating reservoir further downstream is also used as a park $\left(15,700 \mathrm{~m}^{2}\right)$ and the regulating reservoir has a storage capacity of $212,000 \mathrm{~m}^{3}$. The inside diameter and length of the underground regulating reservoir is $10.0 \mathrm{~m}$ and $3.2 \mathrm{~km}$, respectively, the slope is $1 / 1,500$. The regulating reservoir is about $35 \mathrm{~m}$ below the ground surface and has a storage capacity of $212,000 \mathrm{~m}^{3}$ [10].

The Furukawa River underground regulating reservoir was also constructed by the TMG. The Furukawa River is a small urban river with a length of $4.4 \mathrm{~km}$ and a river basin of $8.8 \mathrm{~km}^{2}$ that flows into Tokyo Bay. Numerous buildings and houses line river and a highway passes above the river. Flood damage occurred along the Furukawa River in 2004, causing social unrest among the local inhabitants. As part of the improvements to the river, the TMG designed an underground regulating reservoir in 2008, and this is currently being built. The underground regulating reservoir, which has an internal diameter of $7.5 \mathrm{~m}$ and a length of $3.3 \mathrm{~m}$, is being dug under the Furukawa River. It is being designed to detain $135,000 \mathrm{~m}^{3}$ [11].

The Myoshouji River which is the upstream of the Kanda River flooded frequently in the past. Although the Myoshouji River is a relatively short river, with a length of at $9.7 \mathrm{~km}$ and a basin area of $21.4 \mathrm{~km}^{2}$, the Kanda River in the lower reaches of the Myoshouji River has frequently been influenced by rising water levels when there is heavy rain upstream, such as when the Myoshouji River catchment was flooded during heavy rainfall $(112 \mathrm{~mm} / \mathrm{hr})$ in 2005 . During that event, 895 and 522 houses were inundated above and below ground, respectively. The Saginomiya regulating reservoir is thus currently under construction. The storage capacity of the Saginomiya regulating reservoir is approximately $35,000 \mathrm{~m}^{3}$; as in some of the other regulating reservoirs in the Tokyo metropolitan region, part of the reservoir will be used as a playing field. The total area of the system is approximately $30,000 \mathrm{~m}^{2}$ with the upper level of the regulating reservoir divided into three open spaces, a rest station and a playing field $[12,13]$.

\section{Conclusions}

The Tokyo Metropolitan area frequently encounters heavy rainfall exceeding 100 $\mathrm{mm} /$ hour, particularly as temperatures have increased in recent years. However, many of the existing river improvement schemes implemented by the TMG are only capable of handling a rainfall intensity of $50 \mathrm{~mm} / \mathrm{hr}$. The Tokyo Metropolitan Area is oriented along an east-west axis, extending westward to the a mountainous area approximately 1000 to $2000 \mathrm{~m}$ above sea level. Many of the small rivers in Tokyo have their origins in these mountains and then flow downward, across the Kanto floodplain and into Tokyo Bay. It is on this floodplain that many of the rivers improvement schemes are under way as these areas are prone to flood damage, particularly in the central part of Tokyo. Most of the projects conducted to date have consisted of improvements to revetments, retention basins, regulating reservoirs and diversion channels. Project currently underway in the low-lying eastern areas include storm water detention facilities, inner river development projects, super levee development projects, and 
earthquake reinforcement projects. Some of these projects include construction of tide embankments, water gates and seismic reinforcements to preventing damage from storm surges and earthquakes. In addition, the TMG is also involved in erosion and sediment control projects, landslide control projects, and landslide prevention projects. Rivers are valuable open spaces that can improve the quality of life of residents in densely populated urban areas. Numerous projects have been conducted to create aesthetically pleasing riverside environments with revetments that facilitate the access of users to water. The TMG is now promoting integrated flood control measures that balance the basic policy requirements for flood control systems in the Tokyo metropolitan area with the needs of the public.

\section{References}

[1] Tokyo Metropolitan Government, River Division, Bureau of Construction, River Projects in Tokyo, 2011.

[2] Ministry of Land, Infrastructure, Transport and Tourism, Reports of regional mitigation measures against heavy rains in small rivers, http://www.mlit.go.jp/report/press/river03-kh-ooo126.html

[3] Tokyo Metropolitan Government, Projects for preventing floods in the Tokyo metropolitan area, 2011.

[4] Tokyo Metropolitan Government, Records of flood damage, 2011.

[5] Tokyo Metropolitan Government, Flooding hazard measures in Tokyo metropolitan area, http://www.kensetsu.metro.tokyo.jp//suigai-taisaku /index/index.htm

[6] Tokyo Metropolitan Government, Basic policy regarding heavy rainfall mitigation measures in the Tokyo metropolitan area, http://www.metro.tokyo.jp/INET/KEIKAKU 2007/08/70h8s100.htm.

[7] Sato, K, Y. Kaneko, K. Izumi, T. Nakayama and M. Takezawa, The River Goes Underground, Proc. Of the Int. Symposium on Comprehensive Watershed Management, pp, 539-546, Beijing, China, 1998.

[8] Tokyo Metropolitan Government, C40 Cities Climate Leadership Group C40 Tokyo, Conference on Climate Change, http://www.kensetsu.metro.tokyo.jp/c40/act6-E/practice04.html.

[9] Tokyo Metropolitan Government, Measures against Floods and Storm Surges in Urban Rivers \& Disaster Information Dissemination, 2008.

[10] Tokyo Metropolitan Government, Regulating reservoirs at the Shirako River, http://www.kensetsu.metro.tokyo.jp/yonken/koji2/chikacho.html.

[11] Tokyo Metropolitan Government, Furukawa Underground Regulating Reservoir, http://www.kensetsu.metro.tokyo.jp/ichiken/index.html.

[12] K. Ueki, Flood measures of the Myoushouji River, Construction of the Saginomiya regulating reservoir, homepage3.nifty.com/kouji.ueki/news /11/p0824.html.

[13] Tokyo Metropolitan Government, Measures along the Iruma River in Tokyo, http://www.metro.tokyo.jp/INET/KEIKAKU/2010/70K11200.htm. 